\title{
Occurrence of Lipoteichoic Acid in Oral Streptococci
}

\author{
STEPHEN D. HOGG, ${ }^{1 *}$ ROBERT A. WHILEY, ${ }^{2}$ AND JOHANNES J. DE SOET ${ }^{3}$ \\ Department of Oral Biology, University of Newcastle upon Tyne, Newcastle upon Tyne NE2 $4 B W,{ }^{1}$ and Department of \\ Oral Microbiology, The London Hospital Medical College, London, ${ }^{2}$ United Kingdom, and Department of Oral \\ Microbiology, Academic Center for Dentistry, Amsterdam, The Netherlands ${ }^{3}$
}

\begin{abstract}
The heterogeneous bacterial group known as oral streptococci was screened for the presence of cellular polyglycerolphosphate-containing lipoteichoic acid. This compound was detected in phenol extracts of lyophilized cells by an immunoassay in which polyglycerolphosphate-specific monoclonal antibody was used. Polyglycerolphosphate-containing lipoteichoic acid occurred in all 86 strains of oral streptococci examined except the Streptococcus mitis and Streptococcus oralis strains. This confirms the findings of Rosan (B. Rosan, Science 201:918-920, 1978) and Hamada et al. (S. Hamada, J. Mizuno, S. Kotani, and M. Torii, FEMS Microbiol. Lett. 8:93-96, 1980), is consistent with the results of the taxonomic study of oral streptococci performed by Kilian et al. (M. Kilian, L. Mikkelsen, and J. Henrichsen, Int. J. Syst. Bacteriol. 39:471-484, 1989), who emended the descriptions of Streptococcus sanguis, $S$. oralis, and $S$. mitis, and reflects the phylogenetic relationship among $S$. mitis, S. oralis, and Streptococcus pneumoniae.
\end{abstract}

The term lipoteichoic acid (LTA) has been used to describe a group of closely related macroamphiphiles which are synthesized and primarily located in the cytoplasmic membranes of various gram-positive bacteria $(5,48)$. Historically, LTA has been structurally characterized by an unbranched linear polymer of 1,3-linked glycerol phosphate residues covalently attached to a terminal hydrophobic region comprised of fatty acids. Variations may occur in the length of the polyglycerolphosphate (PGP) chain, which usually does not exceed 40 residues, in the presence of glycosyl substituents and D-alanine on C-2 of the glycerol moiety, and in the structure of the glycolipid anchor. Thus, it is now common to use the term LTAs to indicate this heterogeneity. For reviews see references 10 and 38.

Recently, Fischer (12) has redefined LTAs as macroamphiphiles that contain alditolphosphates as integral parts of the hydrophilic chain. This more liberal definition allows for the inclusion of compounds in which the repeating unit contains glycosyl residues. These polyglycosylalditolphosphate-containing LTAs are very much less common than the classic PGPcontaining LTAs (PGP-LTAs). The wider definition was thought to be necessary to distinguish LTAs from macroamphiphiles which do not contain phosphate residues as an integral part of the repeating structure of the polar moiety and which Fischer (12) refers to as lipoglycans.

Not all gram-positive microorganisms synthesize a form of LTA in its broader sense, and current evidence suggests that the organisms in which it is not present instead elaborate a lipoglycan. This may imply that these two classes of compounds could have similar functions, although the nature of the functions is by no means clear. This division between LTA- and lipoglycan-producing microorganisms, as defined by Fischer (12), appears to follow the broad taxonomic line based on guanine-plus-cytosine $(\mathrm{G}+\mathrm{C})$ contents of DNAs in that LTA synthesis seems to occur predominantly in members of the low-G+C-content Clostridium-Bacillus branch of the grampositive eubacteria rather than in members of the high-G $+C$ content actinomycete branch as defined by Fox et al. (15). However, to date, only a relatively few species belonging to a small number of bacterial genera have been examined.

\footnotetext{
* Corresponding author. Phone: 44191222 7862. Fax: 44191222 6137. E-mail: steve.hogg@ncl.ac.uk.
}

Both PGP- and non-PGP-LTA-synthesizing species are represented within the oral streptococci, and since Schleifer et al. (35), Ruhland and Fiedler (34), and, more recently, Sutcliffe (37) have suggested that LTAs may have value as chemotaxonomic markers, it is clearly of interest to know the distribution of amphiphile types within these species.

Previously, Rosan (32) and Hamada et al. (17) showed that Streptococcus mitis and Streptococcus sanguis biotype II (also previously known as biotype B) do not synthesize PGP-LTA. However, since these studies there have been profound changes in the classification of oral streptococci, including emended descriptions of some species and descriptions of a number of new species, such as $S$. mitis and $S$. sanguis (for a review see reference 19). Therefore, it is appropriate at this juncture to reexamine the oral streptococci to determine which species synthesize PGP-LTA.

In this study we report on the occurrence of PGP-LTA in 86 strains of oral streptococci representing all of the currently recognized species isolated from humans in this group.

\section{MATERIALS AND METHODS}

Bacterial strains and growth conditions. The strains used in this study had been identified previously on the basis of DNA-DNA hybridization data obtained by the $\mathrm{S} 1$ nuclease method (47) or the results of biochemical tests, including a panel of phenotypic tests described by Beighton et al. (3).

For chemical extraction, strains were grown overnight anaerobically in $20 \mathrm{ml}$ of Todd-Hewitt broth (Oxoid, Ltd., Basingstoke, Hants, United Kingdom). Cells were harvested by centrifugation, transferred to microcentrifuge tubes in $1 \mathrm{ml}$ of distilled water, pelleted by centrifugation, lyophilized, and stored at $-20^{\circ} \mathrm{C}$.

Preparation of bacterial phenol extracts. Lyophilized cells, prepared as described above, were resuspended in $0.5 \mathrm{ml}$ of distilled water to which an equal volume of $90 \%(\mathrm{wt} / \mathrm{vol})$ phenol was added. The mixture was heated at $70^{\circ} \mathrm{C}$ with frequent mixing for $1 \mathrm{~h}$ before the aqueous phase was separated by centrifugation and removed. The phenol phase was then reextracted with $0.5 \mathrm{ml}$ of distilled water, and the two aqueous phases were pooled, dialyzed against water, lyophilized, and stored at $-20^{\circ} \mathrm{C}$.

Production of monoclonal antibody. Splenocytes specific for PGP-LTA were induced by immunizing BALB/c mice with a cocktail comprising equal quantities of Streptococcus sobrinus HG961, HG962, HG970, and HG977, all of which were fresh isolates as described by De Soet et al. (8). Cultures of each strain were washed and diluted in phosphate-buffered saline (PBS) to an optical density at $600 \mathrm{~nm}$ of 1.0 before storage at $-20^{\circ} \mathrm{C}$. The mice were injected intravenously with $100 \mu \mathrm{l}$ of the microbial mixture; this was followed 2 weeks later and at two weekly intervals with two intraperitoneal injections consisting of $100 \mu \mathrm{l}$ of microbial mixture supplemented with Freund's complete adjuvant. Four days prior to fusion, the mice were given a booster consisting of an additional $100 \mu \mathrm{l}$ of the microbial mixture.

Splenocytes were isolated and fused with myeloma cells as described previously (7). Hybridomas were screened by testing culture fluids for antibody ac- 
tivity with a direct enzyme-linked immunosorbent assay (ELISA) against either whole intact cells of $S$. sobrinus or a crude glucosyltransferase-LTA mixture prepared as described by Umesaki et al. (39) by using S. sobrinus HG459. Further screening for hybridomas that produced antibodies specific for PGP was performed with a direct ELISA, using plates coated with deacylated cardiolipin produced by hydrolysis of cardiolipin (Sigma, Poole, United Kingdom) in 15\% ammonium hydroxide as described by Courtney et al. (6). All hybridoma cell lines which produced antibodies to PGP were subcloned twice, and the monoclonal antibody activity was tested with the ELISA against LTA isolated from Streptococcus mutans and $S$. sanguis. Cross-reactivity with other antigens was determined by probing sodium dodecyl sulfate-polyacrylamide gel electrophore sis (SDS-PAGE) gels blotted onto positively charged nylon membranes as described below. Monoclonal antibodies for experimental purposes were produced by using a continuous dialyzing system, as described by van Raamsdonk et al (40).

Screening bacterial extracts for PGP-LTA. Bacterial extracts were screened for PGP-LTA by performing a competitive ELISA (23) in which LTA extracted from $S$. sanguis NCTC $7863^{\mathrm{T}}$ (T = type strain) with phenol (21) and purified by hydrophobic interaction chromatography (14) was used as the standard.

Briefly, the wells of Immunol 1 microtiter plates (Dynatech Laboratories, Inc., McLean, Va.) were coated with antigen by treating each well with $75 \mu \mathrm{l}$ of a standard LTA solution $\left(5.0 \mu \mathrm{g} \cdot \mathrm{ml}^{-1}\right)$ in PBS at $4^{\circ} \mathrm{C}$ overnight. Some wells were not treated with standard LTA and served as controls for nonspecific interactions, which were blocked by incubating all wells with $150 \mu \mathrm{l}$ of $10 \%$ ( $\mathrm{vol} / \mathrm{vol})$ fetal calf serum (Gibco, Paisley, United Kingdom) in PBS containing $0.05 \%$ (wt/vol) Tween 80 (PBST). LTA standards were prepared from a stock solution $\left(10 \mu \mathrm{g} \cdot \mathrm{ml}^{-1}\right)$ in PBS by serial twofold dilution.

Samples $(75 \mu \mathrm{l})$ of standard LTA or streptococcal extract dissolved in $1.0 \mathrm{~m}$ of PBS were incubated with an equal volume of PGP-LTA-specific monoclonal antibody OMVU13 diluted 1:1,000. The wells were washed five times with PBST before addition of $75 \mu$ l of alkaline phosphatase-conjugated goat anti-mouse immunoglobulin $\mathrm{G}$ (Sigma) diluted to the recommended working strength. The wells were then washed a minimum of 10 times with PBST before the phosphatase substrate (Sigma) was added. Optical densities at $405 \mathrm{~nm}$ were determined with a Titertek Multiscan model MCC/340 MK II instrument (Flow Laboratories, Sittingbourne, United Kingdom). Antibody dilutions were prepared in PBST containing fetal calf serum, and all preparations were incubated for $1 \mathrm{~h}$ at $37^{\circ} \mathrm{C}$.

All LTA measurements, including measurements for standards, were determined in quadruplicate. Values that were more than twice the background value were considered positive for the presence of LTA

Immunoblotting. Lyophilized bacterial cell phenol extracts or lyophilized whole cells from 20 -ml cultures were treated with Laemmli sample buffer $\left(100^{\circ} \mathrm{C}\right.$, $5 \mathrm{~min})$, separated by SDS-PAGE (7.5\% [ $\mathrm{vol} / \mathrm{vol}]$ acrylamide gel), electrophoretically blotted onto a positively charged nylon membrane (Zeta-Probe; Bio-Rad, Hemel Hempstead, United Kingdom), and probed with OMVU13. The blots were developed with 5-bromo-4-chloro-3-indolylphosphate toluidinium (salt) (BCIP)-nitroblue tetrazolium (Cambridge Bio/Science, Cambridge, United Kingdom) following incubation with alkaline phosphatase-conjugated antimouse immunoglobulin G (Sigma). Nonspecific interactions were blocked by using PBST containing 5\% (wt/vol) skim milk powder, which was also used to prepare all antibody dilutions. All preparations were incubated for $60 \mathrm{~min}$ at room temperature.

\section{RESULTS AND DISCUSSION}

Monoclonal antibody OMVU13 recognized the glycerolphosphate-glycerol epitope of deacylated cardiolipin, PGPLTA isolated from $S$. mutans 292A, Lactobacillus casei 267 , and Enterococcus hirae 283/1, which was kindly supplied by W. Fischer, PGP-LTA isolated from $S$. sanguis NCTC $7863^{\mathrm{T}}$ by us, and commercially available LTA from $S$. mutans (Sigma) in an ELISA (data not shown). Immunoblotting of SDS-PAGE-separated phenol extracts of representatives of each species studied revealed a cell component from each strain that had a mobility identical to that of standard PGP-LTA isolated from $S$. sanguis NCTC $7863^{\mathrm{T}}$ and little evidence of cross-reactions with other extracted compounds (data not shown). The PGPLTA migrated close to but not coincident with the leading edge of the electrophoresis gel and exhibited some heterogeneity in PGP chain length, which is a feature of this compound (29). Sometimes small amounts of faster-migrating material were detected, which may have been LTA degradation products or extracted cardiolipin. Taken together, our results show that OMVU13 recognizes PGP and detects PGP-LTA in cell phenol extracts.
A total of 86 strains, representing all of the recognized oral species of streptococci isolated from humans, including most type strains and a variety of other reference and wild strains, were examined for the presence of PGP-LTA by using OMVU13. The results are shown in Table 1 together with the origins, sources, and identities of the strains. All of the strains except those belonging to Streptococcus oralis and $S$. mitis were PGP-LTA positive.

Although PGP-LTA has been recognized as an important gram-positive antigen for some time and has been associated with a variety of host-bacterium interactions, the number of bacterial species in which it has been positively identified remains limited (11). In the human mouth, PGP-LTA has been implicated in the adhesion of Streptococcus pyogenes to pharyngeal epithelial cells (2) and the adhesion of oral commensal streptococci to tooth surfaces (22). This compound has also been found to promote bone resorption in tissue culture (20), to induce severe inflammatory responses in rat periodontium (1), to activate complement by both the classical (28) and alternate pathways (9), and to activate macrophages (36). The polyanionic nature of PGP-LTA permits cation binding, and Rose et al. (33) have suggested that this compound may function as a calcium buffer in dental plaque, thereby affecting the availability of calcium ions and possibly the dissociation equilibria of tooth mineral. From the oral perspective, it should be particularly interesting to establish which oral streptococci elaborate this polymer, since the streptococci are numerically dominant in the oral cavity.

It is also pertinent to reexamine LTA synthesis in view of the recent advances made in the taxonomy of this difficult and heterogeneous group of bacteria (26). Although PGP-LTA synthesis was found to be widespread among the species examined, strains of both $S$. mitis and $S$. oralis were exceptional in this respect, which supports the results of previous studies of PGP-LTA synthesis in oral streptococci $(17,32)$ and is consistent with the results of more detailed taxonomic studies which have shown that these organisms are closely related to Streptococcus pneumoniae. Thus, S. mitis, $S$. oralis, and $S$. pneumoniae form a small cluster, which exhibits $99 \%$ 16S rRNA sequence homology, within a larger cluster termed the mitis group, which also contains Streptococcus gordonii, S. sanguis, and Streptococcus parasanguis (25). Currently, 16S rRNA sequence data is not available for Streptococcus crista.

There have been some reports suggesting the possibility of atypical behavior with regard to PGP-LTA synthesis in some strains of $S$. oralis. Thus, Vickerman and Jones (42), using rabbit polyclonal antibody, identified PGP-LTA in strain C5, which had been received as $S$. oralis but which had also been shown to resemble $S$. gordonii phenotypically (41). Our data confirm the identity of strain $\mathrm{C} 5$ as a $S$. gordonii strain and also confirm that this organism produces PGP-LTA (Table 1).

Ohkuni et al. (31), using a polyclonal antiserum to LTA prepared in rabbits by injecting whole cells of $E$. hirae, detected cross-reacting material in culture supernatants of 4 of $17 \mathrm{~S}$. oralis strains and 5 of $13 \mathrm{~S}$. mitis strains in a study of the role of oral streptococci in the etiology of Kawasaki disease. However, Ohkuni et al. (31) also detected PGP-cross-reacting material in the culture supernatant of S. mitis NCTC $12261^{\mathrm{T}}$, which was not detected in phenol extracts of cells in the present study, and also failed to detect PGP-LTA in the culture supernatants of $S$. sanguis ATCC $10556^{\mathrm{T}}\left(=\mathrm{NCTC} 7863^{\mathrm{T}}\right)$ and S. gordonii NCTC $7865^{\mathrm{T}}$.

The close phylogenetic relationship among $S$. oralis, $S$. mitis, and $S$. pneumoniae (25) is reflected in the cell wall compositions of these organisms. Kilpper-Bälz et al. (27) have shown that $S$. oralis walls characteristically contain choline, and 
TABLE 1. Streptococcal strains used in this study, their sources, and their abilities to synthesize PGP-LTA

\begin{tabular}{|c|c|c|c|c|}
\hline Strain & Sender(s) ${ }^{a}$ & Method used to identify ${ }^{b}$ & Source & PGP-LTA \\
\hline \multicolumn{5}{|l|}{ Streptococcus crista strains } \\
\hline CC5A & Handley & DNA & Dental plaque & + \\
\hline AK1 & Handley & Phenotype & Throat & + \\
\hline CR3 & Handley & DNA & Dental plaque & + \\
\hline CR311 ${ }^{\mathrm{T}}\left(=\operatorname{NCTC} 12479^{\mathrm{T}}\right)$ & Handley & DNA & Periodontal abscess & + \\
\hline \multicolumn{5}{|l|}{ Streptococcus gordonii strains } \\
\hline H44 & LHMC & Phenotype & Dental plaque & + \\
\hline NCTC 10231 & NCTC & DNA & & + \\
\hline NCTC 3165 & NCTC & DNA & Pyorrhea & + \\
\hline $\mathrm{H} 730$ & LHMC & Phenotype & Dental plaque & + \\
\hline NCTC 7868 & NCTC & DNA & Strain Challis & + \\
\hline NCTC $7865^{\mathrm{T}}$ & NCTC & DNA & $\mathrm{SBE}^{c}$ & + \\
\hline M5 & Rosan & DNA & Dental plaque & \\
\hline GPF1 & Carlsson & Phenotype & Dental plaque & + \\
\hline F90A & Colman & DNA & Strain Perryer & + \\
\hline $\mathrm{C} 5$ & Vickerman & Phenotype & Oral cavity & + \\
\hline \multicolumn{5}{|l|}{ Streptococcus sanguis strains } \\
\hline AC59 & LHMC & Phenotype & Dental plaque & + \\
\hline P695 & LHMC & Phenotype & Dental plaque & + \\
\hline KPE2 & Carlsson & DNA & Dental plaque & + \\
\hline PC3829 & LHMC & Phenotype & Dental plaque & + \\
\hline $\mathrm{AC} 3137$ & LHMC & Phenotype & Dental plaque & + \\
\hline PC3821 & LHMC & Phenotype & Dental plaque & + \\
\hline HPC1 & Carlsson & DNA & Dental plaque & + \\
\hline NP506 & LHMC & Phenotype & Dental plaque & + \\
\hline NCTC $7863^{\mathrm{T}}$ & NCTC & DNA & SBE & + \\
\hline SK96 & Ranke & DNA & Dental plaque & + \\
\hline \multicolumn{5}{|l|}{ Streptococcus parasanguis strains } \\
\hline FW213 & Handley & DNA & Unknown & + \\
\hline MGH143 & Handley & DNA & Urine & + \\
\hline EF3711 & LHMC & DNA & Dental plaque & + \\
\hline UC 4989 & Handley & DNA & Throat & + \\
\hline $85-81$ & $\mathrm{CDC}$ & DNA & Blood & + \\
\hline $2156-81 \mathrm{~A}$ & $\mathrm{CDC}$ & DNA & Blood & + \\
\hline SS897 & $\mathrm{CDC}$ & DNA & Throat & + \\
\hline $\operatorname{SS} 898^{\mathrm{T}}\left(=\operatorname{ATCC} 15912^{\mathrm{T}}\right)$ & $\mathrm{CDC}$ & DNA & Throat & + \\
\hline \multicolumn{5}{|l|}{ Streptococcus mutans strains } \\
\hline 161 & Perch & Phenotype & Blood & + \\
\hline KPSK2 & Carlsson & Phenotype & Human mouth & + \\
\hline B48 & LHMC & Phenotype & Dental plaque & + \\
\hline OMZ 175 & Guggenheim & Phenotype & Dental plaque & + \\
\hline 4177 & Perch & Phenotype & Blood & + \\
\hline NCTC $10449^{\mathrm{T}}$ & NCTC & Phenotype & Carious dentine & + \\
\hline \multicolumn{5}{|l|}{ Streptococcus sobrinus strains } \\
\hline SL-1 ${ }^{\mathrm{T}}\left(=\right.$ ATCC $\left.33478^{\mathrm{T}}\right)$ & Coykendall & Phenotype & Dental plaque & + \\
\hline OMZ 65 & Guggenheim & Phenotype & Dental plaque & + \\
\hline 279 & Perch & Phenotype & Human teeth & + \\
\hline B13 & Edwardsson & Phenotype & Dental plaque & + \\
\hline B542 & LHMC & Phenotype & Dental plaque & + \\
\hline \multicolumn{5}{|l|}{ Streptococcus constellatus strains } \\
\hline NCTC 10714 & NCTC & DNA & Throat & + \\
\hline NCTC 11063 & NCTC & DNA & Throat & + \\
\hline NCTC 5389 & NCTC & DNA & Unknown & + \\
\hline \multicolumn{5}{|l|}{ Streptococcus intermedius strains } \\
\hline $\begin{array}{l}\text { NCDO } 2227^{\mathrm{T}}(=\text { ATCC } \\
\left.33397^{\mathrm{T}}\right)\end{array}$ & NCDO & DNA & Unknown & + \\
\hline UNS 35 & Unsworth & DNA & Brain abscess & + \\
\hline \multicolumn{5}{|l|}{ Streptococcus anginosus strains } \\
\hline NCTC $10713^{\mathrm{T}}$ & NCTC & DNA & Throat & + \\
\hline NMH 10 & Wren & DNA & Perforated ulcer & + \\
\hline G5:3 & Mejare & DNA & Dental plaque & + \\
\hline $2236-81$ & $\mathrm{CDC}$ & DNA & Blood & + \\
\hline PC4890 & LHMC & DNA & Dental plaque & + \\
\hline NCTC 11062 & NCTC & DNA & Dental root canal & + \\
\hline KR 687 & Ruoff & DNA & Axillary abscess & + \\
\hline KR 455 & Ruoff & DNA & Urine & + \\
\hline \multicolumn{5}{|l|}{ Streptococcus mitis strains } \\
\hline NCTC 10712 & NCTC & DNA & Sputum & - \\
\hline
\end{tabular}


TABLE $1-$ Continued

\begin{tabular}{|c|c|c|c|c|}
\hline Strain & Sender $(\mathrm{s})^{a}$ & Method used to identify ${ }^{b}$ & Source & $\overline{\text { PGP-LTA }}$ \\
\hline PP53 & Carlsson & DNA & Dental plaque & - \\
\hline $\mathrm{NS}^{2} 1^{\mathrm{T}}\left(=\operatorname{NCTC} 12261^{\mathrm{T}}\right)$ & Carlsson & DNA & Human oral cavity & - \\
\hline K208 & Colman & DNA & Abscessed tooth & - \\
\hline \multicolumn{5}{|l|}{ Streptococcus vestibularis strains } \\
\hline OP81 & Carlsson & DNA & Dental plaque & + \\
\hline $\mathrm{MM}^{\mathrm{T}}\left(=\mathrm{NCTC} 12166^{\mathrm{T}}\right)$ & LHMC & DNA & Vestibular mucosa & + \\
\hline JW3 & LHMC & DNA & Vestibular mucosa & + \\
\hline \multicolumn{5}{|l|}{ Streptococcus salivarius strains } \\
\hline M36 & LHMC & DNA & Dental plaque & + \\
\hline $\mathrm{H} 53$ & LHMC & Phenotype & Dental plaque & + \\
\hline A385 & LHMC & DNA & Dental plaque & + \\
\hline NCTC 8606 & NCTC & DNA & & + \\
\hline $\mathrm{H} 50$ & LHMC & Phenotype & Dental plaque & + \\
\hline GSS2 & Carlsson & Phenotype & Saliva & + \\
\hline B242 & LHMC & Phenotype & Dental plaque & + \\
\hline KPS1 & Carlsson & Phenotype & Dental plaque & + \\
\hline B128 & LHMC & Phenotype & Dental plaque & + \\
\hline P511 & LHMC & Phenotype & Dental plaque & + \\
\hline T267 & LHMC & Phenotype & Dental plaque & + \\
\hline M236 & LHMC & Phenotype & Dental plaque & + \\
\hline ATCC 9759 & ATCC & Phenotype & & + \\
\hline NCTC $8618^{\mathrm{T}}$ & NCTC & DNA & Throat & + \\
\hline \multicolumn{5}{|l|}{ Streptococcus oralis strains } \\
\hline LVG1 $^{\mathrm{T}}\left(=\operatorname{NCTC} 11427^{\mathrm{T}}\right)$ & Carlsson & DNA & Vestibular mucosa & - \\
\hline B88 & LHMC & Phenotype & Dental plaque & - \\
\hline M254 & LHMC & Phenotype & Dental plaque & - \\
\hline M524 & LHMC & Phenotype & Dental plaque & - \\
\hline OS51 & Carlsson & DNA & Saliva & - \\
\hline GPD1 & Carlsson & Phenotype & Dental plaque & - \\
\hline OPA1 & Carlsson & DNA & Dental plaque & - \\
\hline H362 & LHMC & Phenotype & Dental plaque & - \\
\hline PC1467 & LHMC & DNA & Dental plaque & - \\
\hline NCTC 7864 & NCTC & DNA & SBE & - \\
\hline
\end{tabular}

${ }^{a}$ Strains were received from the following sources: ATCC, American Type Culture Collection, Rockville, Md.; Carlsson, J. Carlsson, Dental School, University of Umea, Umea, Sweden; CDC, R. Facklam, Centers for Disease Control and Prevention, Atlanta, Ga.; Colman, G. Colman, Central Public Health Laboratory, Colindale, London, United Kingdom; Coykendall, A. Coykendall, School of Dental Medicine, University of Connecticut, Farmington, Conn.; Edwardsson, S. Edwardsson, Department of Oral Microbiology, School of Dentistry, University of Lund, Malmö, Sweden; Guggenheim, B. Guggenheim, Zahnarztliches Institut der Universitat Zurich, Zurich, Switzerland; Handley, P. Handley, Department of Cell and Structural Biology, Manchester University, Manchester, United Kingdom; LHMC, Department of Oral Microbiology, The London Hospital Medical College, London, United Kingdom; Mejare, B. Mejare, School of Dentistry, University of Lund, Malmö, Sweden; NCTC, National Collection of Type Cultures, Public Health Laboratory Service, Colindale, London, United Kingdom; Perch, B. Perch, State Serum Institute, Copenhagen, Denmark; Ranke, E. and B. Ranke, Bakteriologie Laboratorium Klinik, Universitat Hamburg, Hamburg, Germany; Rosan, B. Rosan, Department of Microbiology, School of Medicine, University of Philadelphia, Philadelphia, Pa.; Ruoff, K. Ruoff, Massachusetts General Hospital, Boston, Mass.; Unsworth, P. Unsworth, Central Public Health Laboratory, Colindale, London, United Kingdom; Wren, M. Wren, North Middlesex Hospital, London, United Kingdom.

${ }^{b}$ Strains were identified or identities were confirmed by DNA-DNA hybridization (DNA) or a panel of phenotypic tests (Phenotype). For descriptions of the DNA-DNA hybridization tests see references 18 (for $S$. crista), 45 (for S. parasanguis), 46 (for S. vestibularis and S. salivarius), 43 (for $S$. salivarius), 47 (for S. anginosus, S. constellatus, and $S$. intermedius), and 43 (for $S$. gordonii, S. sanguis, S. mitis, and $S$. oralis). For descriptions of the phenotypic tests see references 3 (for $S$. crista, $S$. gordonii, S. sanguis, S. parasanguis, S. mitis, S. vestibularis, S. salivarius, and $S$. oralis), 4 (for S. mutans and $S$. sobrinus), and 44 (for $S$. constellatus, S. anginosus, and $S$. intermedius).

${ }^{c} \mathrm{SBE}$, subacute bacterial endocarditis.

Gillespie et al. (16) have found a C-polysaccharide-like, choline-containing antigen in both $S$. oralis and $S$. mitis which is similar to the compound found in $S$. pneumoniae. Furthermore, $S$. pneumoniae has been shown to be unique in that it elaborates a teichoic acid and an LTA with an identical chain structure (13), and since some radiolabelled choline is incorporated into membrane components of $S$. oralis (24), it has been suggested that this species may in fact produce a cholinecontaining macroamphiphile similar to that of $S$. pneumoniae. It is, therefore, possible to speculate that members of this group share common structural LTA features.

This divergence in LTA type within a closely related group of streptococci is of considerable interest, not only to chemotaxonomists, but also to those who are pursuing the elusive function of bacterial macroamphiphiles. With this in mind, it may be significant that both $S$. oralis and $S$. mitis, non-PGP-
LTA producers, are the major pioneer colonizers of cleaned tooth surfaces (30).

\section{ACKNOWLEDGMENTS}

We thank Leslie Old for her skillful technical assistance and Iain Sutcliffe for useful discussions about LTAs. We thank W. Fischer for supplying some of the LTAs used to characterize OMVU13.

\section{REFERENCES}

1. Bab, I. A., M. N. Sela, I. Ginsburg, and T. Dishon. 1979. Inflammatory lesions and bone resorption induced in the rat periodontium by lipoteichoic acid of Streptococcus mutans. Inflammation 3:345-358.

2. Beachey, E. H., and W. A. Simpson. 1982. The adherence of group A streptococci to oropharyngeal cells: the lipoteichoic acid adhesin and fibronectin receptor. Infection 10:107-111.

3. Beighton, D., J. M. Hardie, and R. A. Whiley. 1991. A scheme for the identification of viridans streptococci. J. Med. Microbiol. 35:367-372. 
4. Beighton, D., R. R. B. Russell, and R. A. Whiley. 1991. A simple biochemical scheme for the differentiation of Streptococcus mutans and Streptococcus sobrinus. Caries Res. 25:174-178.

5. Coley, J., M. Duckworth, and J. Baddiley. 1972. The occurrence of lipoteichoic acids in the membranes of gram-positive bacteria. J. Gen. Microbiol. 73:587-591.

6. Courtney, H. S., W. A. Simpson, and E. H. Beachey. 1986. Relationship of critical micelle concentrations of bacterial lipoteichoic acids to biological activities. Infect. Immun. 51:414-418.

7. De Soet, J. J., P. J. van Dalen, M. J. Pavicic, and J. de Graaff. 1990. Enumeration of mutans streptococci in clinical samples by using monoclona antibodies. J. Clin. Microbiol. 28:2467-2472.

8. De Soet, J. J., C. van Loveren, A. J. Lammens, M. J. Pavicic, C. H. Homburg, J. M. ten Cate, and J. de Graaff. 1991. Differences in cariogenicity between fresh isolates of Streptococcus sobrinus and Streptococcus mutans. Caries Res. 25:116-122.

9. Fiedel, B. A., and R. W. Jackson. 1978. Activation of the alternative complement pathway by a streptococcal lipoteichoic acid. Infect. Immun. 22:286287.

10. Fischer, W. 1988. Physiology of lipoteichoic acids in bacteria. Adv. Microb. Physiol. 29:233-302.

11. Fischer, W. 1990. Glycolipids, phosphoglycolipids and sulfoglycolipids, p 123-234. In M. Kates (ed.), Handbook of lipid research, vol. 6. Plenum Press, New York, N.Y.

12. Fischer, W. 1994. Lipoteichoic acids and lipoglycans, p. 199-215. In J.-M Ghuysen and R. Hakenbeck (ed.), New comprehensive biochemistry, vol. 27. Elsevier Science, Amsterdam, The Netherlands.

13. Fischer, W., T. Behr, R. Hartmann, J. Peterkatalinic, and H. Egge. 1993. Teichoic acid and lipoteichoic acid of Streptococcus pneumoniae possess identical chain structures. A reinvestigation of teichoid acid (c polysaccharide). Eur. J. Biochem. 215:851-857.

14. Fischer, W., H. U. Koch, and R. Haas. 1983. Improved preparation of lipoteichoic acids. Eur. J. Biochem. 133:523-530.

15. Fox, G. E., E. Stackebrandt, R. B. Hespell, J. Gibson, J. Maniloff, T. A. Dyer, R. S. Wolfe, W. E. Balch, R. S. Tanner, L. J. Magrum, L. B. Zablen, R. Blakemore, R. Gupta, L. Bonen, B. J. Lewis, D. A. Stahl, K. R. Luehrsen, K. N. Chen, and C. R. Woese. 1980 . The phylogeny of prokaryotes. Science 209:457-463.

16. Gillespie, S. H., P. H. M. McWhinney, S. Patel, J. G. Raynes, K. P. W. McAdam, R. A. Whiley, and J. M. Hardie. 1993. Species of alpha-hemolytic streptococci possessing a C-polysaccharide phosphorylcholine-containing antigen. Infect. Immun. 61:3076-3077.

17. Hamada, S., J. Mizuno, S. Kotani, and M. Torii. 1980. Distribution of lipoteichoic acids and other amphipathic antigens in oral streptococci. FEMS Microbiol. Lett. 8:93-96.

18. Handley, P. A. Coykendall, D. Beighton, J. M. Hardie, and R. A. Whiley. 1991. Streptococcus crista sp. nov., a viridans streptococcus with tufted fibrils, isolated from the human oral cavity and throat. Int. J. Syst. Bacteriol. 41: 543-547.

19. Hardie, J. M., and R. A. Whiley. 1994. Recent developments in streptococcal taxonomy: their relation to infections. Rev. Med. Microbiol. 5:151-162.

20. Hausmann, E., O. Lüderitz, K. Knox, and N. Weinfeld. 1975. Structura requirements for bone resorption by endotoxin and lipoteichoic acid. J. Dent. Res. 54(Special Issue B):B94-B99.

21. Hogg, S. D., and G. Embery. 1982. Blood-group-reactive glycoprotein from human saliva interacts with lipoteichoic acid on the surface of Streptococcus sanguis cells. Arch. Oral Biol. 27:261-268.

22. Hogg, S. D., and J. E. Manning. 1988. Inhibition of adhesion of viridans streptococci to fibronectin-coated hydroxyapatite beads by lipoteichoic acid. J. Appl. Bacteriol. 65:483-489.

23. Hogg, S. D., and L. A. Old. 1993. The wall associated lipoteichoic acid of Streptococcus sanguis. Antonie van Leeuwenhoek Int. J. Gen. Mol. Microbiol. 63:29-34.

24. Horne, D. S., and A. Tomasz. 1993. Possible role of a choline-containing teichoic acid in the maintenance of normal cell shape and physiology in Streptococcus oralis. J. Bacteriol. 175:1717-1722.

25. Kawamura, Y., X. Hou, F. Sultana, H. Miura, and T. Ezaki. 1995. Determination of 16S rRNA sequences of Streptococcus mitis and Streptococcus gordonii and phylogenetic relationships among members of the genus Streptococcus. Int. J. Syst. Bacteriol. 45:406-408.

26. Kilian, M., L. Mikkelsen, and J. Henrichsen, 1989. Taxonomic study of viridans streptococci: description of Streptococcus gordonii sp. nov. and emended descriptions of Streptococcus sanguis (White and Niven 1946), Streptococcus oralis (Bridge and Sneath 1982), and Streptococcus mitis (Andrewes and Horder 1906). Int. J. Syst. Bacteriol. 39:471-484.

27. Kilpper-Bälz, R., P. Wenzig, and K. H. Schleifer. 1985. Molecular relationships and classification of some viridans streptococci as Streptococcus oralis and emended description of Streptococcus oralis (Bridge and Sneath 1982). Int. J. Syst. Bacteriol. 35:482-488.

28. Loos, M., F. Clas, and W. Fischer. 1986. Interaction of purified lipoteichoic acid with the classical complement pathway. Infect. Immun. 53:595-599.

29. Maurer, J. J., and S. J. Mattingly. 1991. Molecular analysis of lipoteichoic acid from Streptococcus agalactiae. J. Bacteriol. 173:487-494.

30. Nyvad, B., and M. Kilian. 1987. Microbiology of the early colonization of human enamel and root surfaces in vivo. Scand. J. Dent. Res. 95:369-380.

31. Ohkuni, H., Y. Todome, M. Mizuse, N. Ohtani, H. Suzuki, H. Igarashi, Y. Hashimoto, T. Ezaki, K. Harada, Y. Imada, S. Ohkawa, and S. Kotani. 1993. Biologically active extracellular products of oral viridans streptococci and the aetiology of Kawasaki disease. J. Med. Microbiol. 39:352-362.

32. Rosan, B. 1978. Absence of glycerol teichoic acids in certain oral streptococci. Science 201:918-920.

33. Rose, R. K., S. D. Hogg, and R. P. Shellis. 1994. A quantitative study of calcium-binding by isolated streptococcal cell-walls and lipoteichoic acidcomparison with whole cells. J. Dent. Res. 73:1742-1747.

34. Ruhland, G. J., and F. Fiedler. 1987. Occurrence and biochemistry of lipoteichoic acids in the genus Listeria. Syst. Appl. Microbiol. 9:40-46.

35. Schleifer, K. H., J. Kraus, C. Dvorak, R. Kilpper Bälz, M. D. Collins, and W. Fischer. 1985. Transfer of Streptococcus lactis and related streptococci to Lactococcus, new genus. Syst. Appl. Microbiol. 6:183-195.

36. Standiford, T. J., D. A. Arenberg, J. M. Danforth, S. L. Kunkel, G. M. VanOtteren, and R. M. Strieter. 1994. Lipoteichoic acid induces secretion of interleukin-8 from human blood monocytes: a cellular and molecular analysis. Infect. Immun. 62:119-125.

37. Sutcliffe, I. C. 1994. The lipoteichoic acids and lipoglycans of gram-positive bacteria: a chemotaxonomic perspective. Syst. Appl. Microbiol. 17:467-480.

38. Sutcliffe, I. C., and N. Shaw. 1991. Atypical lipoteichoic acids of grampositive bacteria. J. Bacteriol. 173:7065-7069.

39. Umesaki, Y., Y. Kawai, and M. Mutai. 1977. Effect of Tween 80 on GTF production in Streptococcus mutans. Appl. Environ. Microbiol. 34:115-119.

40. van Raamsdonk, M., J. J. De Soet, and J. de Graaff. 1993. Effect of monoclonal antibodies on the colonization of rats by Streptococcus sobrinus. Caries Res. 27:31-36

41. Vickerman, M. M., D. B. Clewell, and G. W. Jones. 1992. Glucosyltransferase phase variation in Streptococcus gordonii modifies adhesion to saliva-coated hydroxyapatite surfaces in a sucrose-independent manner. Oral Microbiol. Immunol. 7:118-120.

42. Vickerman, M. M., and G. W. Jones. 1995. Sucrose-dependent accumulation of oral streptococci and their adhesion-defective mutants on saliva-coated hydroxyapatite. Oral Microbiol. Immunol. 10:175-182.

43. Whiley, R. A. 1987. A taxonomic study of oral streptococci. Ph.D. thesis London University, London, United Kingdom.

44. Whiley, R. A., and D. Beighton. 1991. Emended descriptions and recognition of Streptococcus constellatus, Streptococcus intermedius, and Streptococcus anginosus as distinct species. Int. J. Syst. Bacteriol. 41:1-5.

45. Whiley, R. A., H. Y. Fraser, C. W. Douglas, J. M. Hardie, A. M. Williams, and M. D. Collins. 1990. Streptococcus parasanguis sp. nov., an atypical viridans Streptococcus from human clinical specimens. FEMS Microbiol. Lett. 68: 115-121.

46. Whiley, R. A., and J. M. Hardie. 1988. Streptococcus vestibularis sp. nov. from the human oral cavity. Int. J. Syst. Bacteriol. 38:335-339.

47. Whiley, R. A., and J. M. Hardie. 1989. DNA-DNA hybridization studies and phenotypic characteristics of strains within the 'Streptococcus milleri group.' J. Gen. Microbiol. 135:2623-2633.

48. Wicken, A. J., and K. W. Knox. 1975. Lipoteichoic acids: a new class of bacterial antigen. Science 187:1161-1167. 